\title{
Oxford Unicondylar Knee Arthroplasty Hybrid and Cementless Fixation: Is There Any Difference in Short-term Follow-up?
}

\author{
Oxford Unikondiler Diz Artroplastinde Hibrid ve Çimentosuz Fiksasyon: Kısa Süreli \\ Takipte Fark Var mı?
}

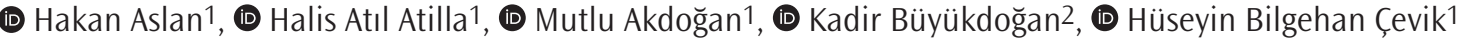 \\ 1University of Health Sciences Turkey, Dıșkapı Yıldırım Beyazıt Training and Research Hospital, Clinic of Orthopaedics and Traumatology, Ankara, \\ Turkey \\ ${ }^{2}$ Koç University Faculty of Medicine, Department of Orthopaedics and Traumatology, İstanbul, Turkey
}

\begin{abstract}
Introduction: Despite a faster recovery, low complication rate, and good functional results, it has been reported that unicondylar knee arthroplasty (UKA) may have high revision rates. Aseptic loosening and pain are the most common causes of UKA revision. The use of cementless and hybrid UKA has been presented as a solution to improve the fixation of prosthetic components. The main purpose of this study was to compare the early clinical outcomes and quality of fixation of cementless and hybrid UKA radiologically.
\end{abstract}

Methods: A retrospective study was established with patients who received 37 cementless and 41 hybrid UKA in a minimum 2 -year follow-up period. The patients' clinical outcomes were evaluated using the Oxford knee score, EuroQol-5 dimensions, EuroQol-visual analog scale, knee injury and osteoarthritis outcome score, and knee range of motion. The fixation of UKA components was evaluated with the varus-valgus angle of the tibial-femoral component, and the incidence of the radiolucent $(\mathrm{RL})$ line at both the tibial and femoral componentbone interface on the radiograph.

Results: There was no significant difference in any clinical outcome measurement $(p>0.05)$. There was no significant difference between the varus-valgus and flexion-extension angles of the femoral and tibial components in both groups $(p>0.05)$. There were significantly more tibial RL in the hybrid group than in the cementless group $(p=0.025)$. There was no significant difference in the incidence of RL at the femoral component-bone interface ( $p=0.691)$.

Conclusion: The cementless group showed significantly less tibial RL than the hybrid group in UKA. Although there were no clinically significant differences between cementless and hybrid UKAs, cementless UKA may be preferred to prevent possible prosthesis loosening.

Keywords: UKA, unicondylar, unicompartmental, cementless, hybrid

\section{öZ}

Amaç: Her ne kadar daha hızı iyileșme, düşük komplikasyon oranı ve iyi fonksiyonel sonuçlar olsa da unikondiler diz artroplastisinin (UDA) yüksek revizyon oranlarına sahip olabileceği bildirilmiş̧ir. UDA revizyonunun en yaygın nedenleri aseptik gevşeme ve ağrıdır. Çimentosuz ve hibrit UKA kullanımı, protez bileșenlerinin fiksasyonunu iyileștirmek için bir çözüm olarak sunulmuştur. Bu çalışmanın temel amacı, çimentosuz ve hibrid UDA'nın erken klinik sonuçlarını ve radyolojik olarak fiksasyon kalitesini karşılaştırmaktır.

Yöntemler: En az 2 yıllık izlem süresi içinde 37 çimentosuz ve 41 hibrid UDA uygulanan hastalarda retrospektif bir çalışma tasarlandı. Hastaların klinik sonuçları Oxford diz skoru, EuroQol-5 ölçeği, EuroQol-görsel analog skalası, diz yaralanması ve osteoartrit sonuç skoru ve diz eklem hareket açıkı̆̆ı ile değerlendirildi. Komponentlerin fiksasyonu ise tibial-femoral komponentin varus-valgus açısı ve radyografide tibial ve femoral komponent-kemik arayüzünde radyolusent (RL) çizgi insidansı ile değerlendirildi.

Bulgular: Hiçbir klinik sonuç ölçütünde anlamlı bir fark yoktu $(p>0,05)$. Her iki grupta femoral ve tibial komponentlerin varus-valgus ve fleksiyon-ekstansiyon açıları arasında anlamlı fark yoktu $(p>0,05)$. Hibrid grupta çimentosuz gruba göre tibial RL anlamlı olarak daha fazlaydı $(p=0,025)$. Femoral komponent-kemik arayüzeyinde RL insidansında anlamlı bir fark yoktu $(p=0,691)$.

Sonuç: UDA uygulanan çimentosuz grup hibrid gruba göre anlamlı derecede daha az tibial RL gösterdi. Çimentosuz ve hibrid UDA'lar arasında klinik olarak anlamlı bir fark olmamakla birlikte, olası protez gevşemesini önlemek için çimentosuz UDA tercih edilebilir.

Anahtar Kelimeler: UDA, unikondiler, unikompartmantal, çimentosuz, hibrid
Address for Correspondence/Yazıșma Adresi: Hüseyin Bilgehan Çevik PhD, University of Health Sciences Turkey, Dıșkapı Yıldırım Beyazıt Training and Research Hospital, Clinic of Orthopaedics and Traumatology, Ankara, Turkey Phone: +90 3125962000 E-mail: bilgehancevik@gmail.com ORCID ID: orcid.org/0000-0003-1945-3715

Cite this article as/Atıf: Aslan H, Atilla HA, Akdoğan M, Büyükdoğan K, Çevik HB. Oxford Unicondylar Knee Arthroplasty Hybrid and Cementless Fixation: Is There Any Difference in Short-term Follow-up?. İstanbul Med J 2021; 22(1): 25-30.

(c) Copyright 2021 by the University of Health Sciences Turkey, Istanbul Training and Research Hospital/istanbul Medical Journal published by Galenos Publishing House.

(C) Telif Hakkı 2021 Să̆lık Bilimleri Üniversitesi istanbul Ĕgitim ve Araștırma Hastanesi/Istanbul Tıp Dergisi, Galenos Yayınevi tarafından basılmıștır.
Received/Geliş Tarihi: 24.06 .2020 Accepted/Kabul Tarihi: 12.12 .2020 


\section{Introduction}

Cemented fixation is the gold standard in total knee arthroplasty (TKA), and successful long-term results have been reported in clinical trials $(1,2)$. However, the lack of remodeling capacity of bone cement has raised questions regarding the long-term results of cemented TKA, especially in young and active patients due to the effect of thirdbody wear (3). Aseptic loosening is most commonly observed in tibial components in TKA, whether cemented or not $(4,5)$. Since the idea of hybrid components emerged in the late 1980s (6), hybrid TKA has become a preferred method in some centers, and comparable success rates have been reported $(7,8)$.

Whether cemented or not in unicondylar knee arthroplasty (UKA), the general view is that the tibial component is at greater risk of aseptic loosening. In addition, if there is pain in the first year postoperatively due to increased stress in the proximal tibia and subchondral bone marrow edema, it can be easily misdiagnosed as aseptic loosening $(9,10)$.

It is generally accepted that uncemented UKA provides biological adherence to bone through bony ingrowth, with the associated theoretical advantages of eliminating cement complications and shortening operation and tourniquet time $(11,12)$. In spite of these advantages of a cementless prosthesis, there is no clear consensus in the literature on the fixation method of the tibial component. Although there are comparative publications in the literature about cemented and cementless UKA, there are no comparative publications on cementless and hybrid (a combination of an uncemented femoral component and a cemented tibial component) UKA. The aim of this study was to compare the early clinical and radiological results of cementless and hybrid UKA.

\section{Methods}

After approval was obtained from University of Health Sciences Turkey, Dıșkapı Yıldırım Beyazıt Training and Research Hospital Local Ethics Board (approval number: 56/07, date: 12.11.2018), this retrospective cohort study was initiated. A retrospective review was performed of 78 consecutive patients with a medial knee arthrosis treated with UKA between January 2014 and December 2018. Radiological data were collected from the picture archiving and communication system.

The clinical and radiological results were compared for patients treated with an Oxford hybrid UKA and uncemented UKA, by a single surgeon (H.A.) with a follow-up of at least 2 years between 2014 and 2017. The demographic properties of the patients are given in Table 1.

The indication for cement usage was given according to the bone hardness test in patients undergoing surgery with the indication of UKA (13). In this test, if the bone surface collapsed (thumb penetrates the bone tissue) when pressure was applied to the trabecular bone surface with the thumb after the tibia was cut, it was deemed unsuitable for the uncemented tibial component, and the cemented one was applied.

The patients' clinical results were evaluated using the oxford knee score, EuroQol-5 dimensions (EQ-5D-3L), EQ-visual analog scale, and the knee injury and osteoarthritis outcome scores (pain, symptom, daily life, sports, and quality of life). Joint range of motion was measured at the final visits. Radiological examination was performed by two independent orthopedic surgeons. Measurements were performed on the patients' anteroposterior and lateral knee radiographs. The varus-valgus and flexion-extension angles of the tibial and femoral components were measured to determine component alignment on

Table 1. Patients' demographic characteristics and clinical results

\begin{tabular}{|c|c|c|c|}
\hline & Cementless $(n=46)$ & Hybrid (n=34) & p-value (MWU) \\
\hline Age & $57.4(47-74)$ & $59.2(47-72)$ & $0.277 *$ \\
\hline Gender (F/M) & $28 / 9$ & $37 / 4$ & $0.156 \int$ \\
\hline Side (R/L) & $22 / 16$ & $23 / 24$ & $0.157 \int$ \\
\hline Height (m) & $1.62(1.52-1.7)$ & $1.63(1.53-1.86)$ & $0.489 *$ \\
\hline Weight (kg) & $80.6(55-112)$ & $81.1(64-108)$ & $0.854 *$ \\
\hline $\mathrm{BMI}\left(\mathrm{kg} / \mathrm{m}^{2}\right)$ & $29.9(23.3-34.5)$ & $30.3(23.1-40.6)$ & $0.719 *$ \\
\hline Follow-up (months) & $34.1(25-38)$ & $35.9(28-65)$ & $0.890 *$ \\
\hline Oxford Knee score & $41.1(12-48)$ & $40.6(20-48)$ & 0.236 \\
\hline EQ-5D-3L & $0.80(0.59-1)$ & $0.79(0.49-1)$ & 0.625 \\
\hline EQ-VAS & $82.8(55-100)$ & $82.9(60-100)$ & 0.869 \\
\hline KOOS - pain & $81.3(1.67-100)$ & $83.7(33.3-100)$ & 0.289 \\
\hline KOOS - symptom & $85.3(42.8-100)$ & $84.5(42.8-100)$ & 0.512 \\
\hline KOOS - daily life & $84.3(14.7-100)$ & $86.1(30.8-100)$ & 0.785 \\
\hline KOOS - sports & $67.0(20-100)$ & $68.7(25.0-100)$ & 0.922 \\
\hline KOOS - quality of life & $82.0(25-100)$ & $79.4(25-100)$ & 0.245 \\
\hline \multicolumn{4}{|l|}{ ROM } \\
\hline Flexion & $112.7^{\circ}\left(95^{\circ}-120^{\circ}\right)$ & $111.4^{\circ}\left(80^{\circ}-120^{\circ}\right)$ & 0.411 \\
\hline Extension & $0.5(0-0)$ & $0.3(0-10)$ & 0.793 \\
\hline
\end{tabular}

Reference values are given in parentheses.

BMI: Body max index, F: female, M: male, R: right, L: left, *: t-test, f: chi square, KOOS: knee injury and osteoarthritis outcome score, EQ-5D-3L: EuroQol-5 dimensions, EQ-VAS: EuroQolvisual analog scale, MWU: Mann-Whitney U test 
radiological evaluation (Figure 1, 2). The incidence of radiological lines at the tibial component-bone and femoral component-bone interfaces was also evaluated.

The bone contact points of the tibial component were divided into six regions according to the technique described by Pandit et al. (14) Zone 1: from the medial tibial plateau to the medial keel, Zone 2: from the medial plateau to the lateral keel, Zone 3: the medial vertical surface of the keel, Zone 4: the lower part of the keel, Zone 5: the lateral vertical surface of the keel, and Zone 6: the lateral to the keel of the medial plateau (Figure 3). Additionally, the bone contact points of the femoral component were measured by a similar technique (Figure 4).

During the follow-up period, insert dislocation occurred in two patients in both groups. All four patients underwent replacement with a $1 \mathrm{~mm}$ thick insert.

\section{Statistical Analysis}

The statistical analysis was performed using SPSS for Windows (SPSS Inc, Chicago, Illinois). Odds ratios and means were compared between groups, with 95\% confidence intervals. Results were considered statistically significant at $p<0.05$. A comparison of proportions method was used to calculate the sample size.

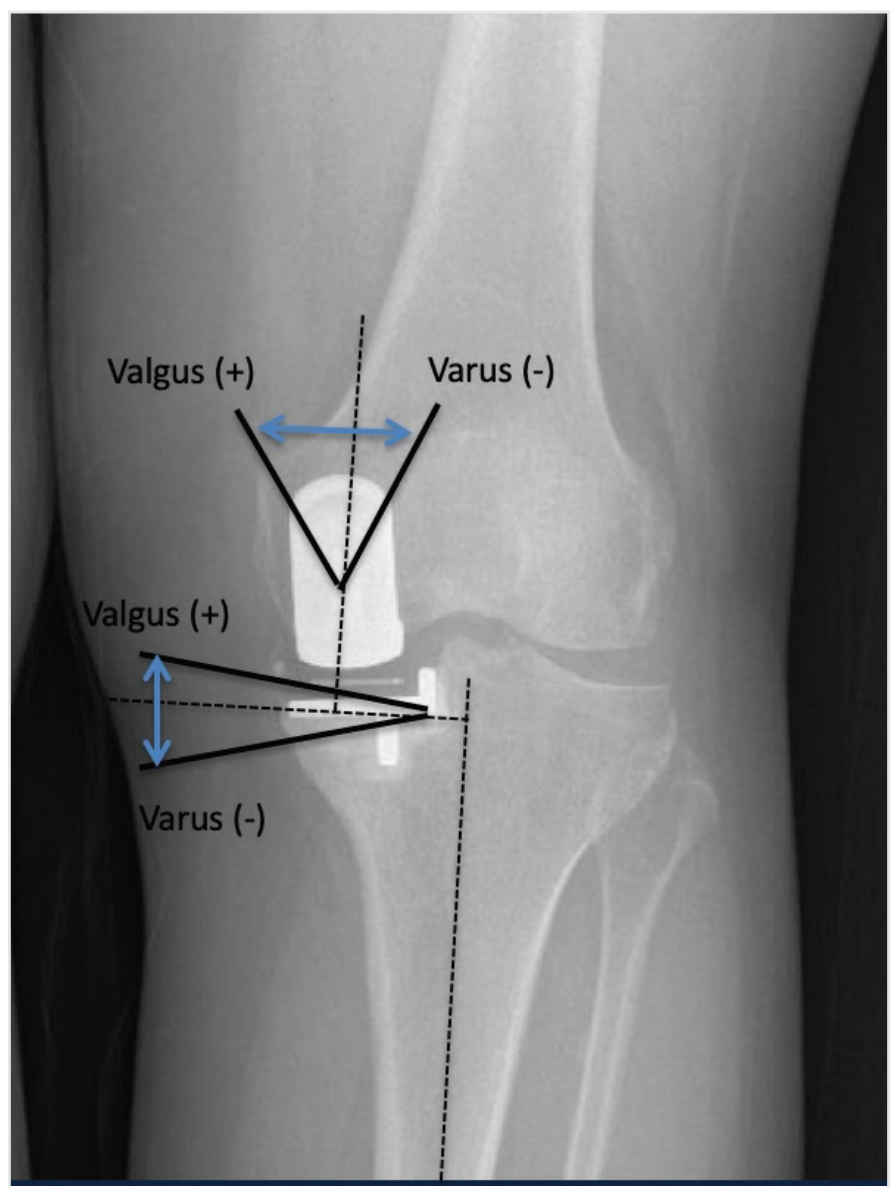

Figure 1. Six zones of RL below the tibial component of the Oxford UKA on anteroposterior radiograph

RL: Radiolucent line, UKA: unicondylar knee arthroplasty

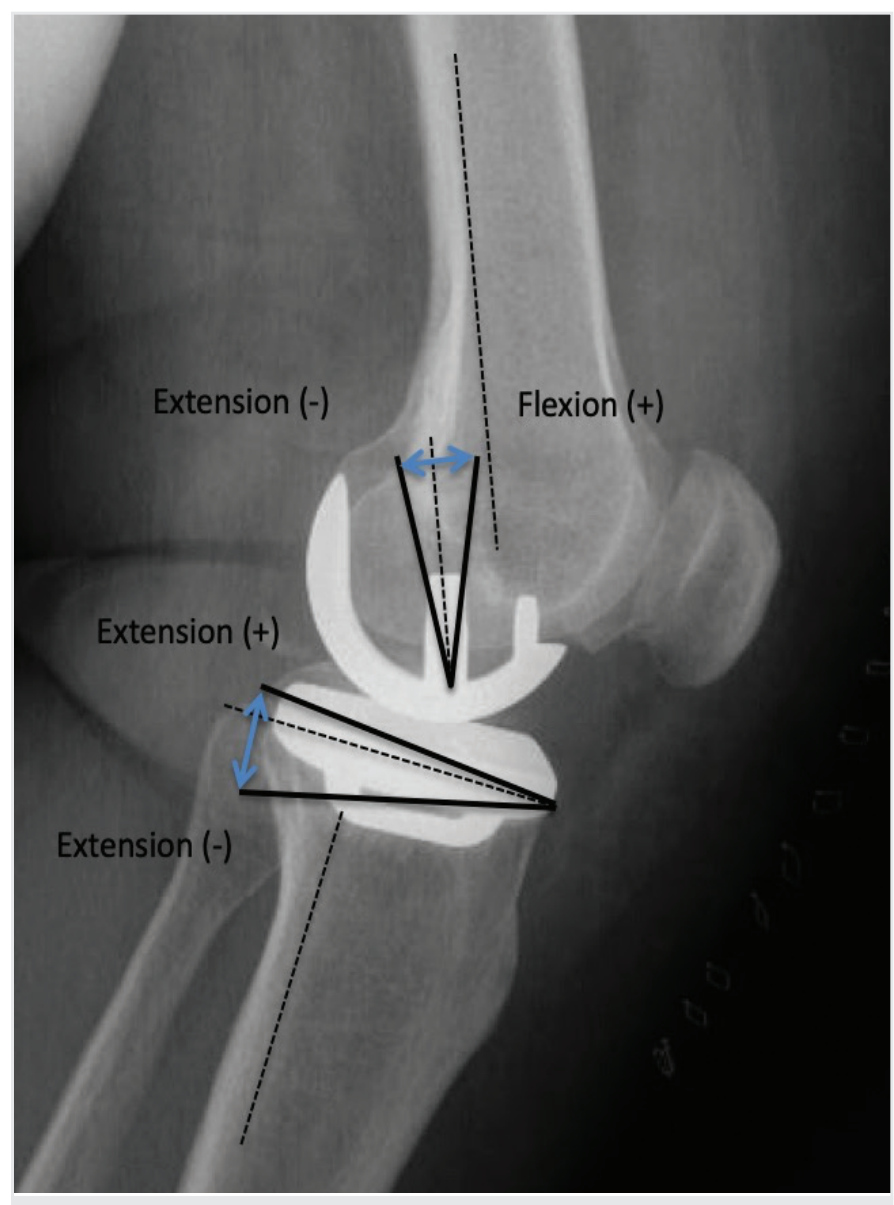

Figure 2. Six zones of RL above the femoral component of the Oxford UKA on lateral radiograph

RL: Radiolucent line, UKA: unicondylar knee arthroplasty

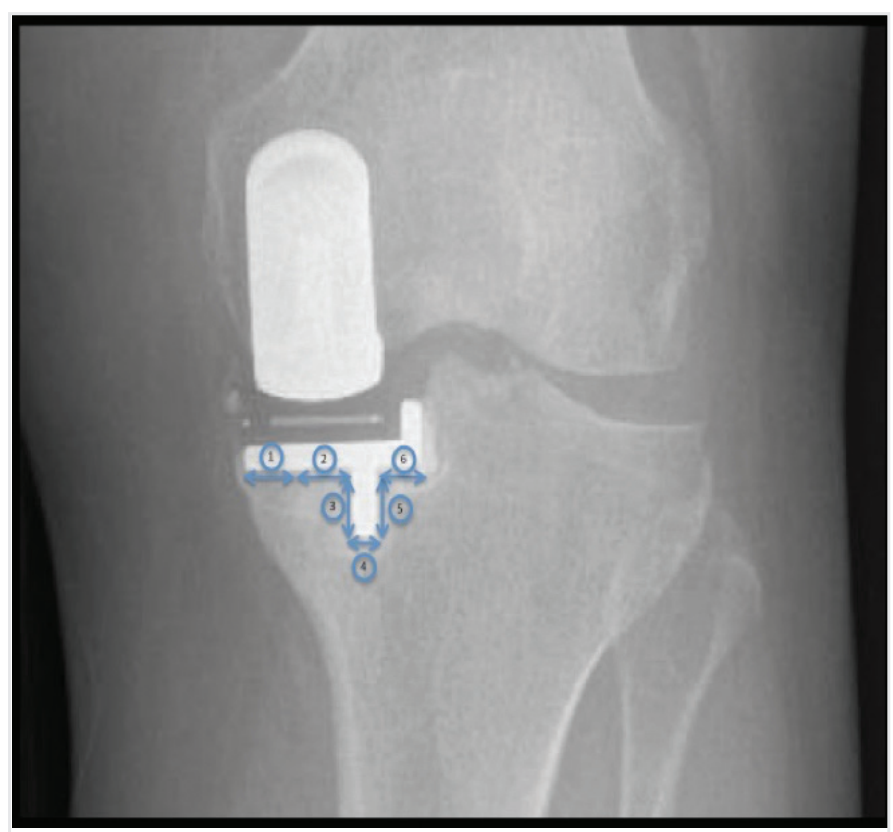

Figure 3. Varus-valgus angles of femoral and tibial components 


\section{Results}

The clinical results of both the cementless and hybrid groups are given in Table 1. Although there was a proportional difference in clinical results in both groups, there was no statistically significant difference between the two groups.

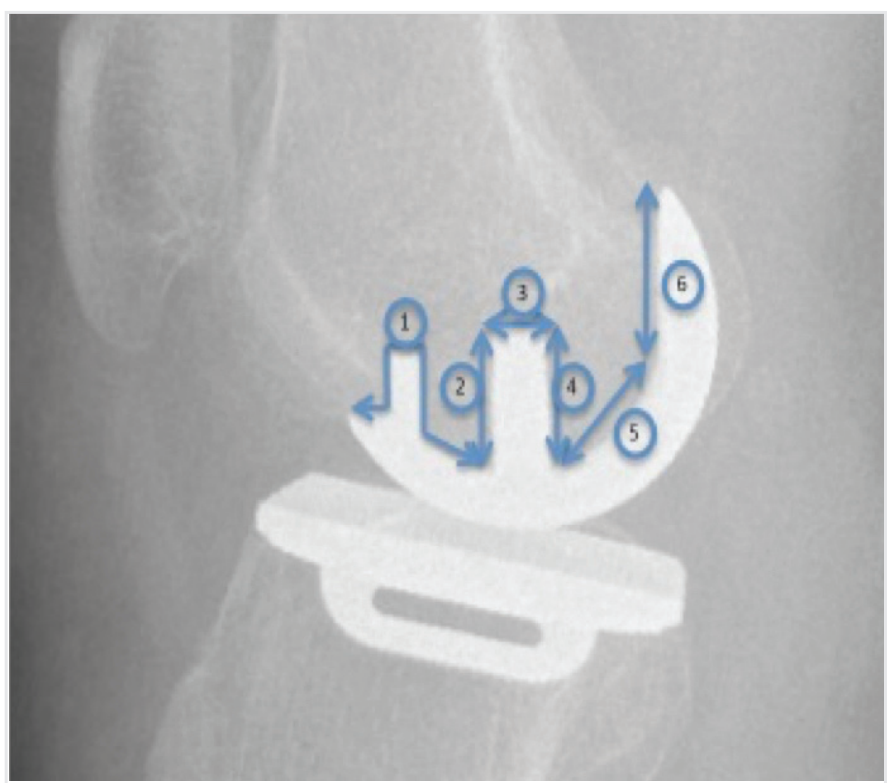

Figure 4. Flexion-extension angles of femoral and tibial components
When the femoral components were evaluated in terms of alignment, in the cementless group, the mean varus-valgus angle was 5.6 2.1 (-6.311.0), and the mean flexion-extension angle was $9.4 \pm 3.3$ (6.5-13.3); in the hybrid group, the mean varus-valgus angle was $7.1 \pm 3.3$ (-8.4-13.2), and the mean flexion-extension angle was $6.8 \pm 4.4$ (-5.6-12.2). When the tibial components were evaluated in terms of alignment, the mean varus-valgus angle in the cementless group was $-0.5 \pm 2.3(-1.4-4.9)$, and the mean flexion-extension angle was $4.5 \pm 2.7$ (-2.6-6.8), and in the hybrid group, the mean varus-valgus angle was $-1.1 \pm 3.4(-2.1-5.5)$, and the mean flexion-extension angle was $4.8 \pm 2.5$ (0.1-9.3). There was no statistically significant difference between the varus-valgus and flexionextension angles of the femoral and tibial components in both groups $(p>0.05)$.

The radiolucent ( $\mathrm{RL}$ ) areas in each zone, the total number of $\mathrm{RL}$ areas, and the numbers of complete and partial RL areas in the patients were compared between the groups (Table 2). When the incidence of RL lines was evaluated in both groups, no complete RL line was observed in any prosthesis. When evaluations were performed of the tibial components alone, a partial RL area was detected in 7 (15.2\%) of the cementless group and 12 (35.2\%) of the hybrid group. The incidence of the RL line at the tibial component interface was higher in the hybrid group than in the cementless group, but the difference was not statistically significant $(p=0.069)$. When partial RL involvement was evaluated according to the region, a total of 13 regions in the cementless group and a total of 32 regions in the hybrid group were detected. This difference was

\section{Table 2. The incidence of radiolucent line}

\section{Tibial Component}

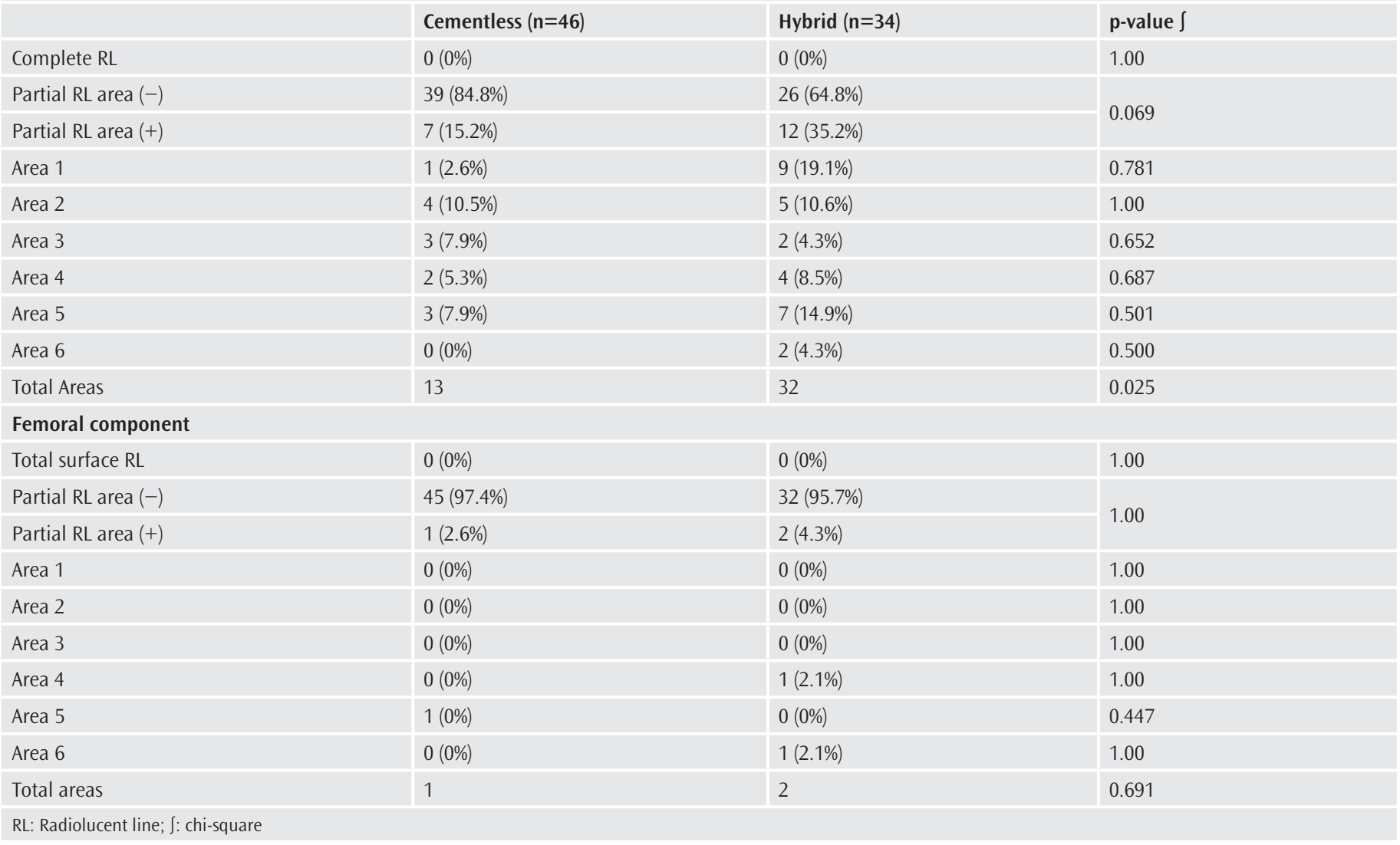


statistically significant $(p=0.025)$. When all the tibial components were considered in the cementless group, the highest rates of partial RL region involvement were determined in Zone 3 and Zone 5, respectively. The total of all partial RL regions was 13 . In the hybrid group, the highest rates of partial RL region involvement in the tibial components were seen in zones 1,5 , and 2 , respectively.

When the femoral components were evaluated among themselves, a partial RL area was detected in one patient of the cementless group and in two patients of the hybrid group. There was no statistically significant difference in the incidence of the partial RL line at the femoral component interface $(p=0.691)$.

\section{Discussion}

There is no comparative study in the literature regarding hybrid vs all uncemented or all cementless UKA. Therefore, the results of this study could only be compared with the results of hybrid vs cementless fixation in TKA.

Cement application is the most widely used fixation method in TKA compared with the cementless and hybrid options. However, there is confusion as to which is the optimum fixation method. In view of the potential late loosening and third-body wear effects of cement, cementless implants have been developed as an alternative method that allows biological fixation and has potential advantages such as the preservation of bone stock for revisions $(3,15,16)$ However, some studies have reported that cementless fixation leads to instability and loosening, especially in the tibial component $(17,18)$. To avoid these problems in the cementless tibial component, the idea of hybrid application was proposed and successful medium- and long-term results of hybrid TKA have been reported (19-22). Behery et al. (23) found that 76 cases of aseptic loosening comprised $10 \%$ with cementless prostheses and $0 \%$ cemented. Early weight-bearing and obesity were reported to cause loosening. Another interesting point of that study was that all the loosened tibial components were seen in patients with a cruciate retaining prosthesis. The authors attributed this to the different femoral rollback kinematics in the two design types, with a different pattern of tibial weight-bearing, which could be implicated in micromotion and failure of osseointegration. In the present study, aseptic loosening was not observed in both cementless and hybrid UKA groups. The probable reason for the lack of aseptic loosening in both groups may be the inadequate follow-up period. However, the higher number of tibial RL lines seen in the hybrid group may be a predictor of future aseptic loosening.

In UKA, the fixation evolution of the components undergoes a process similar to that of TKA. Cementless fixation of tibial and femoral components has been accepted as a widely used method in recent years, whereas cemented prosthesis had previously been the generally accepted method (24). As in TKA, the femoral component in UKA is at a lower risk of loosening than the tibial component. However, there are different views on cementless application of the tibial component in patients with high-level activity expectations, obese patients, and patients with osteoporosis. The design group has argued that the use of cementless application in osteoporotic patients is not a contraindication and does not include any indications different from those for cemented versions (25). In a study of 12 cadaveric knees, Jaeger et al. (26) emphasized that bone quality is important in implant choice, and if bone quality is poor, it will lead to subsidence of the implant. Similarly, in the present study, there was no significant difference between the two groups which had patients with similar demographical properties in terms of RL lines seen in the femoral components.

Stempin et al. (13) stated that they made the decision to use cement intraoperatively by observing the quality of bone visually and by applying the bone hardness test. Accordingly, after the tibial cut is made, pressure is applied to the bone surface with the thumb (index finger in small knees), and a slight deflection is observed on the bone surface. If the resected surface collapses, the stiffness of the bone is considered to be insufficient to provide primary stability of the implant and a cemented component is used (13). In contrast, Campi et al. (11) reported that the problem of bone quality will not affect the results. They stated that as the forces primarily transmitted are compressive, the implant works well with cementless fixation, and neither bone density nor patient age affects the success or failure of a cementless fixation (27). The decision to apply the tibial component with or without cement was also made in this present study according to the bone hardness test.

In the literature, no significant difference has been reported between the functional outcomes of cemented and cementless UKA (28).

Likewise, in the present study, there was no significant difference between cementless and hybrid UKA with respect to functional outcomes.

In the current series, as there was no fracture due to press-fit implantation, the risk reduction can be explained by strict adherence to the technique described by Campi et al. (11), including adequate clearing of peg and keel slots, avoidance of damage to the posterior cortical bone, and delicate impaction using a small hammer to avoid causing a fracture.

Another reason for the success of the current series may be that all operations were performed by a single surgeon and the team is experienced in UKA. The learning curve for UKA is considered to be long, so experience provides minimization of surgical errors. Therefore, the postoperative results can be evaluated without the bias of technical errors.

\section{Study Limitation}

There are a few limitations associated with this study, primarily its retrospective nature and the limited sample size. For arthroplasty cases, a 2-year follow-up period may not be sufficient. The osteolysis and UKA loosening in this early period may be due to undetected infection, inappropriate surgical technique, and/or the choice of fixation (cemented or cementless). The results of this study describe a single surgeon's experience and, therefore, may not be generalizable.

The most important feature of this study is that it is the first study in the literature to compare the clinical and radiological results of cementless and hybrid UKA. 


\section{Conclusion}

The most important finding of the study was that cementless tibial components showed significantly less RL than components of the hybrid group. Cementless and hybrid UKA have been used as a popular method in recent years and are preferred by many surgeons, and now it may be possible to predict what problems might be encountered, especially in obese and osteoporotic patients in long-term follow-up.

\section{Ethics}

Ethics Committee Approval: This study approval was obtained from University of Health Sciences Turkey, Dışkapı Yıldırım Beyazıt Training and Research Hospital Local Ethics Board (approval number: 56/07, date: 12.11.2018).

Informed Consent: Retrospective study.

Peer-review: Externally peer-reviewed.

Authorship Contributions: Surgical and Medical Practices - H.A., M.A.; Concept - H.A., H.A.A., M.A., K.B., H.B.C..; Design - H.A., H.A.A., M.A., K.B., H.B.C.; Data Collection or Processing - H.A., H.A.A., M.A., K.B., H.B.C..; Analysis or Interpretation - H.A., H.A.A., M.A., K.B., H.B.Ç.; Literature Search - H.A., H.A.A., M.A., K.B., H.B.Ç.; Writing - H.A., H.A.A., M.A., K.B., H.B.C..

Conflict of Interest: No conflict of interest was declared by the authors.

Financial Disclosure: The authors declared that this study received no financial support.

\section{References}

1. Attar FG, Khaw FM, Kirk LM, Gregg PJ. Survivorship analysis at 15 years of cemented press-fit condylar total knee arthroplasty. J Arthroplasty 2008; 23: 344-9.

2. Roberts VI, Esler CN, Harper WM. A 15-year follow-up study of 4606 primary total knee replacements. J Bone Joint Surg Br 2007; 89: 1452-6.

3. Julin J, Jämsen E, Puolakka T, Konttinen YT, Moilanen T. Younger age increases the risk of early prosthesis failure following primary total knee replacement for osteoarthritis. A follow-up study of 32,019 total knee replacements in the Finnish Arthroplasty Register. Acta Orthop 2010; 81: 413-9.

4. Schroer WC, Berend KR, Lombardi AV, Barnes CL, Bolognesi MP, Berend ME, et al. Why are total knees failing today? Etiology of total knee revision in 2010 and 2011. J Arthroplasty 2013; 28(Suppl 8): 116-9.

5. Sharkey PF, Lichstein PM, Shen C, Tokarski AT, Parvizi J. Why are total knee arthroplasties failing today--has anything changed after 10 years? J Arthroplasty 2014; 29: 1774-8.

6. Duffy GP, Murray BE, Trousdale RR. Hybrid total knee arthroplasty analysis of component failures at an average of 15 years. J Arthroplasty 2007; 22: 1112-5.

7. McLaughlin JR, Lee KR. Hybrid total knee arthroplasty: 10- to 16-year followup. Orthopedics 2014; 37: 975-7.

8. Faris PM, Keating EM, Farris A, Meding JB, Ritter MA. Hybrid total knee arthroplasty: 13-year survivorship of AGC total knee systems with average 7 years followup. Clin Orthop Relat Res 2008; 466: 1204-9.

9. Jacobs CA, Christensen CP, Karthikeyan T. Subchondral Bone Marrow Edema Had Greater Effect on Postoperative Pain After Medial Unicompartmental Knee Arthroplasty Than Total Knee Arthroplasty. J Arthroplasty 2016; 31: 491 4.
10. Kleeblad LJ, van der List JP, Zuiderbaan HA, Pearle AD. Regional Femoral and Tibial Radiolucency in Cemented Unicompartmental Knee Arthroplasty and the Relationship to Functional Outcomes. J Arthroplasty 2017; 32: 3345-51.

11. Campi S, Pandit HG, Dodd CAF, Murray DW. Cementless fixation in medial unicompartmental knee arthroplasty: a systematic review. Knee Surg Sports Traumatol Arthrosc 2017; 25: 736-45.

12. Panzram B, Bertlich I, Reiner T, Walker T, Hagmann S, Gotterbarm T. Cementless unicompartmental knee replacement allows early return to normal activity. BMC Musculoskelet Disord 2018; 19: 18.

13. Stempin R, Kaczmarek W, Stempin K, Dutka J. Midterm Results of Cementless and Cemented Unicondylar Knee Arthroplasty with Mobile Meniscal Bearing: A Prospective Cohort Study. Open Orthop J 2017; 11: 1173-8.

14. Pandit H, Liddle AD, Kendrick BJ, Jenkins C, Price AJ, Gill HS, et al. Improved fixation in cementless unicompartmental knee replacement: five-year results of a randomized controlled trial. J Bone Joint Surg Am 2013; 95: 1365-72.

15. Dalury DF. Cementless total knee arthroplasty: current concepts review. Bone Joint J 2016; 98: 867-73.

16. Harrysson OL, Robertsson O, Nayfeh JF. Higher cumulative revision rate of knee arthroplasties in younger patients with osteoarthritis. Clin Orthop Relat Res 2004: 162-8.

17. Shimagaki H, Bechtold JE, Sherman RE, Gustilo RB. Stability of initial fixation of the tibial component in cementless total knee arthroplasty. J Orthop Res 1990; 8: 64-71.

18. Carlsson A, Björkman A, Besjakov J, Onsten I. Cemented tibial component fixation performs better than cementless fixation: a randomized radiostereometric study comparing porous-coated, hydroxyapatite-coated and cemented tibial components over 5 years. Acta Orthop 2005; 76: 362-9.

19. Duffy GP, Murray BE, Trousdale RR. Hybrid total knee arthroplasty: analysis of component failures at an average of 15 years. J Arthroplasty 2007; 22: 1112-5.

20. Petursson G, Fenstad AM, Havelin LI, Gøthesen Ø, Lygre SH, Röhrl SM, et al. Better survival of hybrid total knee arthroplasty compared to cemented arthroplasty. Acta Orthop 2015; 86: 714-20.

21. Yang JH, Yoon JR, Oh CH, Kim TS. Hybrid component fixation in total knee arthroplasty: minimum of 10-year follow-up study. J Arthroplasty 2012; 27: 1111-8.

22. Pelt CE, Gililland JM, Doble J, Stronach BM, Peters CL. Hybrid total knee arthroplasty revisited: midterm followup of hybrid versus cemented fixation in total knee arthroplasty. Biomed Res Int 2013; 2013: 854871.

23. Behery OA, Kearns SM, Rabinowitz JM, Levine BR. Cementless vs cemented tibial fixation in primary total knee arthroplasty. J Arthroplasty 2017; 32: 1510-5.

24. van der List JP, Sheng DL, Kleeblad LI, Chawla H, Pearle AD. Outcomes of cementless unicompartmental and total knee arthroplasty: a systematic review. Knee 2017; 24: 497-507.

25. Liddle AD, Pandit H, Murray DW, Dodd CA. Cementless unicondylar knee arthroplasty. Orthop Clin North Am 2013; 44: 261-9.

26. Jaeger S, Rieger JS, Bruckner T, Kretzer JP, Clarius M, Bitsch RG. The protective effect of pulsed lavage against implant subsidence and micromotion for cemented tibial unicompartmental knee components: an experimental cadaver study. J Arthroplasty 2014; 29: 727-32.

27. Campi S, Pandit HG, Oosthuizen CR. The Oxford Medial Unicompartmental Knee Arthroplasty: The South African Experience. J Arthroplasty 2018; 33: 1727-31.

28. Pandit H, Jenkins C, Beard DJ, Gallagher J, Price AJ, Dodd CA, et al. Cementless Oxford unicompartmental knee replacement shows reduced radiolucency at one year. J Bone Joint Surg Br 2009; 91: 185-9. 